\title{
Comparing Application Methods for N-fertilizer in the Sugar Beet Crop
}

\author{
Maria Teresa Amaducci, Lorenzo Barbanti*, Gianpietro Venturi \\ Dipartimento di Scienze e Tecnologie Agroambientali, Università di Bologna \\ Viale Fanin 44, 40127 Bologna, Italy
}

Received: 16 January 2003. Accepted: 26 September 2005

\begin{abstract}
Sugar beet seeders have been developed in other countries, in order to place nitrogen into the soil at a few centimeters from the seed. Placing fertilizer has proved safe for seedling emergence, successful in reducing soil residual nitrogen at harvest, sometimes even better-yielding than broadcast applications. In a 3-year research on sugar beet, spreading fertilizer on the soil surface followed by incorporation was compared with placing in rows 6 and 3 $\mathrm{cm}$ far from the seed ones, slightly deeper than the seed, in combination with two rates of urea- $\mathrm{N}, 60$ and $120 \mathrm{~kg}$ $\mathrm{ha}^{-1}$, plus an unfertilized check. The course of soil mineral nitrogen and that of $\mathrm{N}$-uptake were evaluated during crop cycle. Yield and quality were evaluated at harvest. Nitrogen placement close to the seed $(3 \mathrm{~cm})$ negatively affected crop emergence. In the plant-soil system, placement showed a higher soil N-content in the first phases and a lower plant uptake at harvest. As for yield, placement attained a slightly-lower level than broadcasting at $60 \mathrm{~kg}$ $\mathrm{N} \mathrm{ha}^{-1}$ of $\mathrm{N}$, almost the same at 120 . No significant difference in quality was observed between the two patterns. At a certain distance from the seed, placement proved a safe way of applying fertilizer. Its yield and quality, the uptake by the plant and the amount of soil residual-N are comparable with those of broadcast fertilizer; in the case of soil nitrogen, it is perceived that the year/location effect is potentially stronger than that of rate/pattern of application.
\end{abstract}

Key-words: fertilizer placement, nitrates, nitrogen, sugar beet.

\section{Introduction}

Nitrogen placement at drilling has always been unadvisable, because of the high saline effect of $\mathrm{N}$-fertilizers (Giardini, 1992), which poses a major threat to seed viability (Draycott, 1972; Draycott et al., 1983; Draycott and Christenson, 2003).

In recent years, the concern to reduce N-related environmental pollution, associated with nitrogen negative effects on beet quality and with the increase in fertilizer costs (Barbanti, 1989), has stimulated new efforts to improve nutrient efficiency, leading to new studies on $\mathrm{N}$ placement at sowing (Venturi, 1994, Venturi and Amaducci, 2002).

In the first experiences in the UK back in the fifties, placing nitrogen $5 \mathrm{~cm}$ aside from the seed row originated symptoms of phytotoxicity (Prummel, 1957); in later researches, distances of $7 \mathrm{~cm}$ from the seed did not create problems and showed yields equal or better than those of quite higher rates spread on the whole surface (Jensen et al., 1983; Cariolle and Duval, 1994; Vlassak et al., 1991; Vandergeten and Vanstallen, 1991a, 1991b; Van Meirvenne et al., 1991), although with slight increases of root amino-N (Van der Beek and Wilting, 1991), sometimes below the level of statistical significance (Van Meirvenne et al., 1991).

Devising new equipments to place reasonable rates of $\mathrm{N}$ aside from the seed row (Erjala, 1991), at no seed contact, seems to be fostering the diffusion of fertilizer placement (Vigoreux, 1991), although the advantage in early growth appears to be modest, since it takes four weeks to lateral rootlets to reach fertilizer granules 5 cm away (Dunham, 1991a, 1991b).

The overall aim is to improve nitrogen effi- 
ciency, ensuring an easy nutrient availability in the period of maximum crop requirement (Vandergeten and Vanstallen, 1991a), maybe also using slow-release fertilizers (Oertli, 1980), apart from urea and ammonium nitrate, whose ammonia fraction already performs a certain degree of slow release (Vlassak et al., 1991), and apart from N-P-K fertilizers, whose employment has proved feasible (Marcussen, 1991), but of limited interest in Italy, with respect to $\mathrm{P}$ fertiliser requirements (Barbanti and Candolo, 1991).

Among the advantages, it could be listed: i) a starter effect due to a higher nitrogen concentration in the soil solution close to the plant during early growth (Dunham, 1991b); ii) a higher degree of nutrient uptake efficiency (Cariolle, 2000; Cariolle et al., 1991; Vandergeten et al., 1997), thanks to lower leaching-andgaseous losses than in fertilizer broadcasting. In fact, nutrient apparent efficiency varies from 60 to $65 \%$ in broadcasting, according to soil type and weather conditions; in placement it varies from $73-75 \%$ up to $95-98 \%$ in most favourable cases (Fayolle 1991); iii) a lower leaching thanks to slower nitrification of ammonia nitrogen (Dunham, 1991b; Guyot et al., 1991; Vandergeten and Vanstallen, 1991a). In fact, since soil urease quickly turns urea into ammonia and $\mathrm{CO}_{2}$, a higher fertilizer concentration through placement saturates the enzyme, slowing its activity. The delayed availability of $\mathrm{NH}_{4}-\mathrm{N}$ in turn affects that of $\mathrm{NO}_{3}-\mathrm{N}$, thus reducing the risk of leaching.

Nutrient placement close to the seed has proved effective in increasing availability for the plant, while at the same time reducing leaching losses (Vlassak et al., 1991; Vandergeten and Vanstallen, 1991a, 1991b), and residual nitrates in the soil profile at the end of crop cycle (Van Meirvenne et al., 1991). At present, nitrogen placement has become a technique of increasing diffusion, especially as a means to reduce the environmental impact associated with sugar beet growing (ITB, 2003).

The first results obtained in Italy with urea placement have not been so favourable (Amaducci et al., 1992; Barbanti et al., 1992; Mambelli et al., 1994). Therefore, in order to better assess the impact of this technique, a new research was planned, whose results are the object of the present paper.

\section{Materials and methods}

Trials were carried out in Cadriano (Bologna, Italy, $44^{\circ} 33^{\prime} \mathrm{N}$ latitude, $11^{\circ} 21^{\prime} \mathrm{E}$ longitude, 32 $\mathrm{m}$ a.s.l.) in the three years 1994 to 1996, on soils showing the following features (Table 1): loamyclay texture, $\mathrm{pH}$ around neutrality, low carbonates, high levels of available $\mathrm{P}$ and $\mathrm{K}$, adequate levels of organic matter, good cation exchange capacity. They are classified (USDA) as Udic Ustochrept Fine Silty Mixed Mesic.

In the first two years, two fixed rates of $\mathrm{N}$ (60 and $120 \mathrm{~kg} \mathrm{ha}^{-1}$ ) representing a normal range of sugar beet fertilization in Northern Italy, were cross-combined with three application methods: broadcasting on the soil surface followed by incorporation through tine-harrowing, and placement by a separate coulter into the soil at a $3-\mathrm{cm}$ depth, in rows at 3 and $6 \mathrm{~cm}$ from the seed ones. An unfertilized check was added to this combination. In the third year, 3$\mathrm{cm}$ placement was omitted.

In all three years the trial scheme was randomized block with four replications. Throughout the trials, the following options were adopted: Bushel as seed variety; plot surface $32.4 \mathrm{~m}^{2}$; row spacing $0.45 \mathrm{~m}$; seed spacing $7 \mathrm{~cm}$; seeding depth about $2 \mathrm{~cm}$. Seedling thinning in the early phases brought to a crop stand of about 10 plants $\mathrm{m}^{-2}$.

Nitrogen was applied as granular urea both in spreading as in placement. In Italy urea is one of the commonest $\mathrm{N}$-fertilizers at sowing, since it has a good title (46\%), that makes for the ap-

Table 1. Soil physical and chemical properties.

\begin{tabular}{|c|c|c|c|c|}
\hline Soil properties & Unit & 1994 & 1995 & 1996 \\
\hline Sand $2-0.02 \mathrm{~mm}$ & $\begin{array}{l}\% \text { fine } \\
\text { soil }\end{array}$ & 51 & 44 & 47 \\
\hline Silt $0.02-0.002 \mathrm{~mm}$ & “ & 14 & 30 & 33 \\
\hline Clay $<0.002 \mathrm{~mm}$ & “ & 35 & 26 & 20 \\
\hline $\mathrm{pH}\left(\mathrm{H}_{2} \mathrm{O}\right)$ & & 7.7 & 6.4 & 7.3 \\
\hline $\begin{array}{l}\text { Total carbonates } \\
\left(\text { as } \mathrm{CaCO}_{3} \text { ) }\right.\end{array}$ & $\%$ d. w. & 1.6 & $<0.5$ & 1.6 \\
\hline $\begin{array}{l}\text { Organic matter } \\
\text { (Walkley-Black) }\end{array}$ & “ & 1.77 & 1.49 & 1.98 \\
\hline Total N (Kjeldahl) & $\mathrm{g} \mathrm{kg}^{-1}$ & 1.10 & 0.77 & 0.90 \\
\hline $\mathrm{C} / \mathrm{N}$ & & 9.4 & 11.2 & 12.8 \\
\hline C.E.C. & $\mathrm{cmol}_{\mathrm{c}} \mathrm{kg}^{-1}$ & 19.9 & 54.8 & 38.2 \\
\hline $\begin{array}{l}\text { Available } \mathrm{N} \\
\left(0.01 \mathrm{M} \mathrm{CaCl}{ }_{2}\right)\end{array}$ & $\mathrm{mg} \mathrm{kg}^{-1}$ & 29.7 & 7.4 & 21.8 \\
\hline Available $\mathrm{P} \dagger$ & “ & 81 & 55 & 38 \\
\hline Exchangeable $\mathrm{K}\left(\mathrm{BaCl}_{2}\right)$ & " & 282 & 149 & 184 \\
\hline
\end{tabular}

$\dagger$ Olsen method (1994, 1996); Bray \& Kurtz (1995). 
Table 2. Crop husbandry and sampling times.

\begin{tabular}{|c|c|c|c|}
\hline & 1994 & 1995 & 1996 \\
\hline Preceding crop & wheat & wheat & grain sorghum \\
\hline Soil tillage & $\begin{array}{l}\text { ploughing }+ \text { sub-soiling } \\
\quad(0.4+0.15 \mathrm{~m})\end{array}$ & $\begin{array}{l}\text { ploughing }+ \text { sub-soiling } \\
\qquad(0.4+0.15 \mathrm{~m})\end{array}$ & $\begin{array}{l}\text { ploughing }+ \text { sub-soiling } \\
\qquad(0.4+0.15 \mathrm{~m})\end{array}$ \\
\hline $\mathrm{P}_{2} \mathrm{O}_{5}$ supply $\left(\mathrm{kg} \mathrm{ha}^{-1}\right)$ & 150 & 120 & 120 \\
\hline $\mathrm{K}_{2} \mathrm{O}$ supply $\left(\mathrm{kg} \mathrm{ha}^{-1}\right)$ & 50 & 50 & 0 \\
\hline Broadcast N-fertilization & March 14 & March 25 & March 25 \\
\hline Sowing & March 14 & March 25 & March 26 \\
\hline Irrigation for emergence & March 23 & - & - \\
\hline Seedling emergence & April 2 & April 12 & April 20 \\
\hline 4-6 true leaves & May 5 & May 8 & May 5 \\
\hline $8-10$ true leaves & May 20 & - & May 16 \\
\hline Beet singling & May 5 & May 8 & May 10 \\
\hline \multirow[t]{4}{*}{ Soil samplings } & March 31 & April 13 & April 12 \\
\hline & May 26 & May 25 & May 30 \\
\hline & July 18 & July 7 & July 5 \\
\hline & Sept. 10 & Sept. 8 & Sept. 10 \\
\hline \multirow[t]{5}{*}{ Crop samplings } & May 26 & May 23 & May 29 \\
\hline & June 19 & June 15 & June 15 \\
\hline & July 18 & July 5 & July 4 \\
\hline & Aug. 19 & Aug. 2 & Aug. 2 \\
\hline & Sept. 10 & Sept. 6 & Sept. 6 \\
\hline Final harvest & Sept. 10 & Sept. 6 & Sept. 6 \\
\hline
\end{tabular}

plication of adequate N-rates while avoiding unnecessary fertilizer handling. A plot seeder was used, that had been equipped with a bisected fertiliser hopper, in order to place the traditional P-fertilizer in the seed furrow while applying urea aside from it, with a double-disk coulter whose distance from the seed furrow could be easily adjusted. The crop was assured a good, conventional husbandry: no irrigation was applied, except in 1994 for seed germination.

The course of nitrate, ammonium and mineral nitrogen $\left(\mathrm{NO}_{3}-\mathrm{N}, \mathrm{NH}_{4}-\mathrm{N}\right.$ and $\mathrm{N}$-min, extracted by $2 \mathrm{M} \mathrm{KCl}$ ) in the soil was evaluated by means of several samplings during crop cycle (Table 2); the first one was soon after seeding (17-19 DAS), in order to check the status of available $\mathrm{N}$ after fertilizer application; the following ones during the cycle, in order to evaluate nutrient variations as affected by these processes: crop removal, losses to deep layers / to the atmosphere, enrichment from mineralization of previous crops' residues and of soil organic matter.

In each plot, samples were taken from three soil layers (0-0.30, 0.30-0.60 and 0.60-0.90 m from the surface), on the seed row for all treatments and also aside for those involving placedN. More in detail, in the two years 1994 and
1995, in order to investigate space variability of the $\mathrm{N}$-content associated with placement, in the plots with $120 \mathrm{~kg} \mathrm{ha}^{-1}$ of $\mathrm{N}$ applied at $6 \mathrm{~cm}$ on the left of the seed row, soil samples were taken on the seed row, $6 \mathrm{~cm}$ on its right and $9 \mathrm{~cm}$ on its left (Figure 1). By this way, it was intended to evaluate the amount of available nutrient at 3,6,12 $\mathrm{cm}$ from the point of release. In this case, too, sampling covered the three soil layers $0-0.30,0.30-0.60$ and $0.60-0.90 \mathrm{~m}$, at the

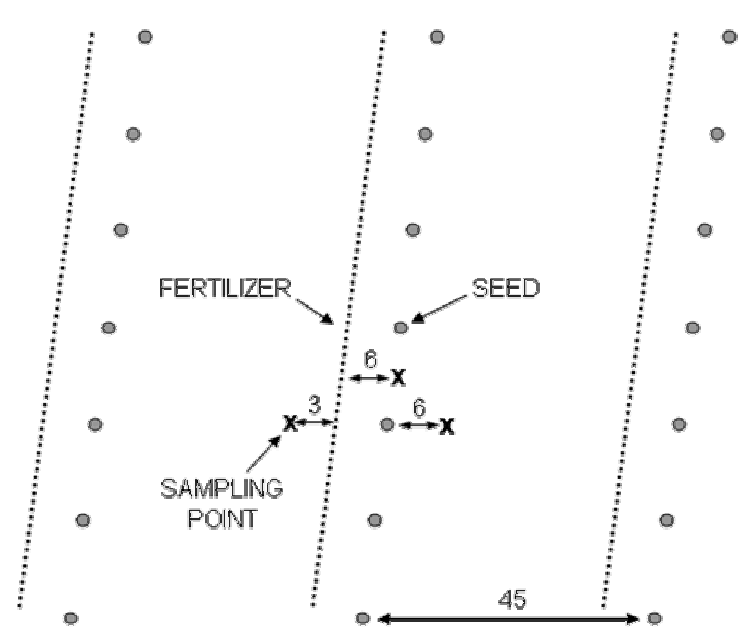

Figure 1. Scheme of soil sampling in 6-cm placement, as related to seed and fertilizer rows. Distances are indicated in centimeters. 
beginning and at the end of crop cycle, respectively at about 15 and 170 days after sowing.

For the calculation of soil nutrient status, an apparent bulk density of $1.3 \mathrm{~kg} \mathrm{~L}^{-1}$ was used for all soil layers.

The plants were subjected to the evaluation of nutrient uptake and partitioning to different organs, i.e. roots, crowns, petioles and leaf blades, during the cycle. To this purpose, five samplings were performed each year (Table 2) on $1-\mathrm{m}^{2}$ surfaces. Plant organic nitrogen was determined with the Kjeldahl procedure; plant nitrate- $\mathrm{N}$ with the method of membrane electrode for specific ions. At final harvest, nitrogen utilization efficiency $\left(\mathrm{NU}_{\mathrm{t}} \mathrm{E}\right)$, as reported by LópezBellido and López-Bellido (2001), was calculated for the total dry weight and for the raw sugar yield, i.e. dividing them by the sum of the organic and nitrate- $\mathrm{N}$ taken up by the plant.

At the same time, root samples on $6.3-\mathrm{m}^{2}$ surfaces were taken and the following yield and quality parameters were assessed, by means of direct measurement or by specific formulae: root yield, sugar content, raw sugar yield, nonsugars content ( $\mathrm{K}, \mathrm{Na}$, amino-N), thick juice purity, percent sugar extractability, white sugar yield and crop financial return.

The whole three-year plant and soil dataset was submitted to ANOVA for the detection of significant effects and of their interactions, after Bartlett's test had been performed in order to assess the homogeneity of variances. As to this, soil data $\left(\mathrm{NH}_{4}-\mathrm{N}, \mathrm{NO}_{3}-\mathrm{N}\right.$ and $\mathrm{N}$-min $)$ were subjected to square-root transformation, in order to homogenise their variances. Differences among means of statistically significant parameters were expressed by the Student - Newman-Keuls test $(\mathrm{P}<0.05)$.

Table 3. Seedling emergence in the average of the years 1994 and 1995. Significant differences $(\mathrm{P}<0.01)$ were found for $\mathrm{N}$-fertilization.

\begin{tabular}{lc}
\hline $\mathrm{N}\left(\mathrm{kg} \mathrm{ha}^{-1}\right)$ & Emergence $(\%$ seed $)$ \\
\hline 0 & $71.0 \mathrm{a}$ \\
$60 \mathrm{Br}$. & $67.8 \mathrm{a}$ \\
$60 \mathrm{Pl} .6$ & $65.4 \mathrm{ab}$ \\
$60 \mathrm{Pl} .3$ & $60.1 \mathrm{~b}$ \\
$120 \mathrm{Br}$. & $60.5 \mathrm{~b}$ \\
$120 \mathrm{Pl} .6$ & $69.4 \mathrm{a}$ \\
$120 \mathrm{Pl} .3$ & $53.9 \mathrm{c}$ \\
\hline
\end{tabular}

a, b, c, etc., significantly different means $(\mathrm{P}<0.05)$.

Br., broadcast; Pl. 6 , placed at $6 \mathrm{~cm} ; \mathrm{Pl} .3$, placed at $3 \mathrm{~cm}$.
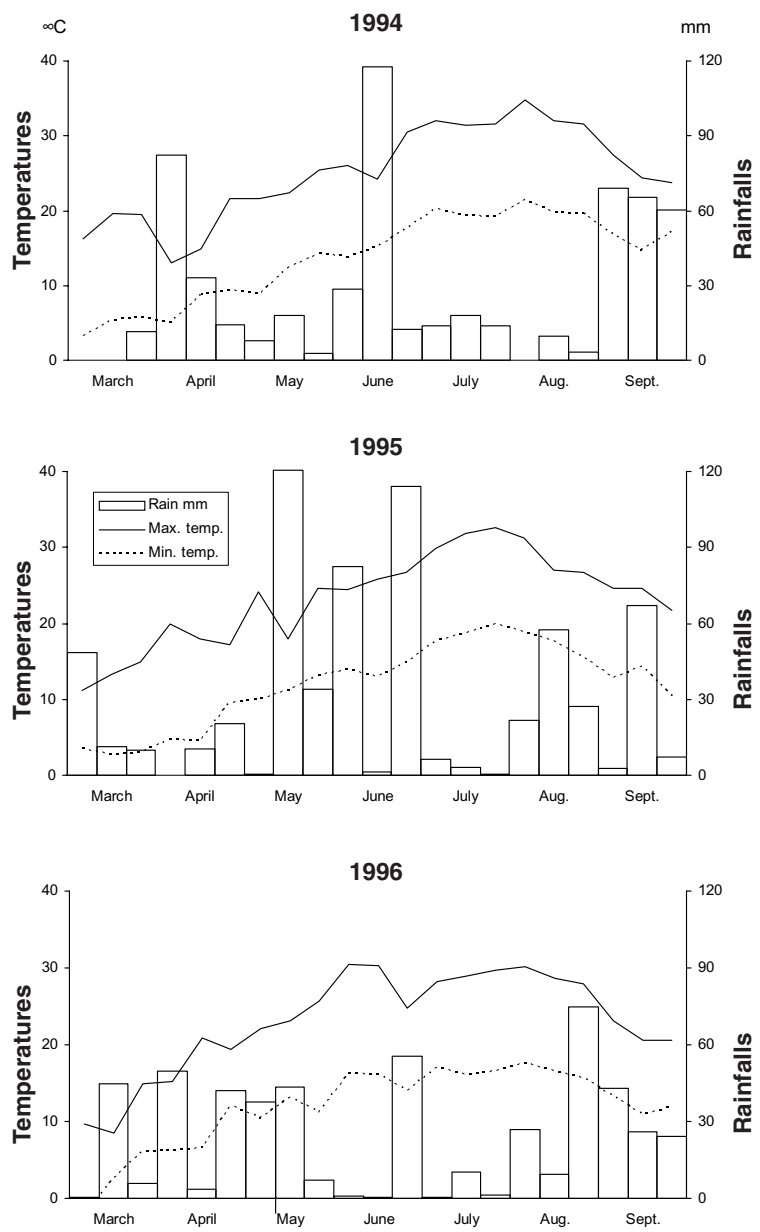

Figure 2. Courses of minima (dashed lines) and of maxima (solid lines) temperatures and of rainfalls (columns) in the period March to September of the years 1994 to 1996.

In discussing the results at harvest, only placement at $6 \mathrm{~cm}$ is considered, which has been investigated for the whole period. Placement at $3 \mathrm{~cm}$ is concerned only for the effects on seedling emergence and on nitrogen soil status.

During crop cycle, rainfalls were much higher in 1995 than in 1994 and in 1996 (Figure 2): in fact, during the three summer months, 300 mm of rain fell in 1995, versus only 210 and 180 , respectively in 1994 and in 1996. In 1995, May was a remarkably wet month with $150 \mathrm{~mm}$, whereas in 1996 no rain was recorded between mid-May to mid-June. As for temperatures, 1996 showed a much warmer April, May and July, both for minima as for maxima. The whole cycle from seedling emergence to final harvest covered 161 days in 1994, 147 in 1995 and 139 in 1996. Thermal time of the whole growth sea- 
Table 4. Yield and quality data in the years 1994 to 1996 . For all the parameters, significant differences $(\mathrm{P}<0.01)$ were found for main effects and for their interactions with years.

\begin{tabular}{|c|c|c|c|c|c|c|c|c|c|c|c|c|}
\hline \multirow{2}{*}{$\begin{array}{c}\mathrm{N} \\
\left(\mathrm{kg} \mathrm{ha}^{-1}\right)\end{array}$} & \multicolumn{3}{|c|}{ Root yield (t ha $\left.{ }^{-1}\right)$} & \multicolumn{3}{|c|}{ Raw sugar yield $\left(\mathrm{t} \mathrm{ha}^{-1}\right)$} & \multicolumn{3}{|c|}{ White sugar yield $\left(\mathrm{t} \mathrm{ha}^{-1}\right)$} & \multicolumn{3}{|c|}{ Financial return $\left(€ \mathrm{ha}^{-1}\right)$} \\
\hline & 1994 & 1995 & 1996 & 1994 & 1995 & 1996 & 1994 & 1995 & 1996 & 1994 & 1995 & 1996 \\
\hline 0 & $102 \mathrm{ab}$ & $92 \mathrm{bc}$ & $48 \mathrm{f}$ & $12.1 \mathrm{ab}$ & $10.7 \mathrm{bc}$ & $6.7 \mathrm{~d}$ & $8.4 \mathrm{abc}$ & $8.0 \mathrm{bc}$ & $5.7 \mathrm{~d}$ & 3137 bd & $2727 \mathrm{~cd}$ & $2308 \mathrm{~d}$ \\
\hline $60 \mathrm{Br}$. & $100 \mathrm{ab}$ & $100 \mathrm{ab}$ & $73 \mathrm{de}$ & $12.7 \mathrm{ab}$ & $11.8 \mathrm{abc}$ & $10.2 \mathrm{bc}$ & $9.0 \mathrm{abc}$ & $8.9 \mathrm{abc}$ & $8.8 \mathrm{abc}$ & $3351 \mathrm{bc}$ & $2956 \mathrm{bcd}$ & $3533 \mathrm{bc}$ \\
\hline $60 \mathrm{Pl} .6$ & $97 \mathrm{ab}$ & $99 \mathrm{ab}$ & $64 \mathrm{e}$ & $11.2 \mathrm{abc}$ & $12.0 \mathrm{abc}$ & $9.4 \mathrm{c}$ & $7.5 \mathrm{c}$ & $9.4 \mathrm{abc}$ & $8.0 \mathrm{bc}$ & $2862 \mathrm{~cd}$ & 3159 bcd & $3361 \mathrm{bc}$ \\
\hline $120 \mathrm{Br}$. & $103 \mathrm{ab}$ & $113 \mathrm{a}$ & $81 \mathrm{~cd}$ & $12.0 \mathrm{abc}$ & $13.5 \mathrm{a}$ & $11.3 \mathrm{abc}$ & $8.0 \mathrm{bc}$ & $10,5 \mathrm{a}$ & $9.6 \mathrm{abc}$ & $3069 \mathrm{bcd}$ & 3445 bc & $3885 \mathrm{ab}$ \\
\hline $120 \mathrm{Pl} .6$ & $105 \mathrm{ab}$ & $99 \mathrm{ab}$ & $78 \mathrm{~cd}$ & $12.1 \mathrm{abc}$ & $11.9 \mathrm{abc}$ & $11.9 \mathrm{abc}$ & $8.1 \mathrm{bc}$ & $9.3 \mathrm{abc}$ & $10.4 \mathrm{ab}$ & $3046 \mathrm{bcd}$ & $3115 \mathrm{bcd}$ & $4334 \mathrm{a}$ \\
\hline
\end{tabular}

a, b, c, etc., significantly different means $(\mathrm{P}<0.05)$. Br., broadcast; Pl. 6, placed at $6 \mathrm{~cm}$.

son, calculated as proposed by Dürr et al. (2003), summed up to almost 2600 growth degree days $\left({ }^{\circ} \mathrm{C}\right)$ in 1994, to about 2300 in 1995 and 1996.

\section{Results and discussion}

\subsection{Effects on crop emergence}

Nitrogen fertilization significantly affected field emergence, especially at the higher rate. This negative effect was enhanced by fertilizer placement at $3 \mathrm{~cm}$. In such case, emergence fell 11\% and $17 \%$ below the unfertilized check, respectively at the lower and at the higher N-rate (Table 3).

The effect on field plots was such, that placement at $3 \mathrm{~cm}$ actually caused misses along beet rows. Taking into account the low salinity index of urea, this effect might be due to an excessive proximity of the fertilizer coulter affecting seedbed quality, as well as to a phytotoxicity created by the process of ammonification of urea, with liberation of toxic $\mathrm{NH}_{3}$ and strong local rise of $\mathrm{pH}$. The latter effect may be involved also in the lower emergence of the high broadcast rate, indicating a possible limit for the amounts of $\mathrm{N}$ which can be safely supplied at seeding. The observed drawback has led to consider $3-\mathrm{cm}$ placement unadvisable, which had been tried as a possible compromise between $\mathrm{N}$ and $\mathrm{P}$ requirements, in the perspective of adopting a single $\mathrm{N}-\mathrm{P}$ fertilizer.

\subsection{Effects on yield and quality of the sugar beet}

At the lower N-rate $\left(60 \mathrm{~kg} \mathrm{ha}^{-1}\right)$, placement at $6 \mathrm{~cm}$ could hardly match the yield attained by fertilizer broadcasting: in the average of the three years, it lost $7 \%$ as raw sugar yield, $5 \%$ as financial return, although in the interaction year $\mathrm{x} \mathrm{N}$ the two methods were seldom statistically differentiated. At the higher nutrient rate (120 $\left.\mathrm{kg} \mathrm{ha}^{-1}\right)$, their yield performance was very close (Table 4). Seen from a different point of view, the lower N-rate yielded about $25 \%$ more than the unfertilized check, when broadcast; only 15$20 \%$, when placed. Conversely, the higher rate showed an increase of 30-35\%, regardless of the application method.

For all the yield parameters reported in table 4 , the above-described pattern repeated in the three years with some between-years differences: it appears as in 1994 a higher N-availability all along the growing season led to a very flat response to the nutrient supplied in any rate or way. The effect on yield was more evident in the following two years and especially in 1996, when root and sugar yield in the unfertilized plots were almost halved with respect to the previous years. On the other hand, top raw-sugar yields varied within a tight range (12-13 $\left.\mathrm{t} \mathrm{ha}^{-1}\right)$, assessing a similar potential in the three years, attained at different N-rates: $60 \mathrm{~kg} \mathrm{ha}^{-1}$ in 1994, 120 in 1995 and in 1996.

In this frame, it is interesting to note that the 1994 crop could not exploit the advantage of a longer growth season in terms of sugar yield and financial return, despite a high root yield: a low sugar content was responsible for this occurrence. The opposite happened in 1996, when a high sugar content was involved in the recovery observed between root and sugar yield, with respect to the previous years.

For all quality parameters (unreported data of non-sugars, thick juice purity and percent sugar extractability), fertilization gave a negative, although not always significant response. No difference between application methods was observed.

In 1995, several non-traditional quality parameters were investigated, too (unreported da- 
Table 5. Nitrogen Utilization Efficiency $\left(\mathrm{NU}_{\mathrm{t}} \mathrm{E}\right)$ at harvest, for total dry weight and raw sugar yield.

\begin{tabular}{lcc}
\hline Factor & $\begin{array}{c}\text { Total dry weight } \\
\left(\mathrm{kg} \mathrm{kg}^{-1}\right)\end{array}$ & $\begin{array}{c}\text { Raw sugar } \\
\left(\mathrm{kg} \mathrm{kg}^{-1}\right)\end{array}$ \\
\hline Year & & \\
1994 & $45.8 \mathrm{c}$ & $22.9 \mathrm{c}$ \\
1995 & $59.9 \mathrm{~b}$ & $34.3 \mathrm{~b}$ \\
1996 & $77.5 \mathrm{a}$ & $48.4 \mathrm{a}$ \\
& $* *$ & $* *$ \\
\hline $\mathrm{N}\left(\mathrm{kg} \mathrm{ha}^{-1}\right)$ & & \\
0 & 55.6 & 29.7 \\
$60 \mathrm{Br}$. & 63.1 & 38.2 \\
$60 \mathrm{Pl} .6$ & 61.8 & 36.7 \\
$120 \mathrm{Br}$. & 62.9 & 33.9 \\
$120 \mathrm{Pl} .6$ & 62.0 & 37.7 \\
& n.s. & n.s. \\
\hline
\end{tabular}

$\mathrm{a}, \mathrm{b}$, c, etc., significantly different means $(\mathrm{P}<0.05)$. Br., broadcast; Pl. 6 , placed at $6 \mathrm{~cm}$

ta): they were scantily affected by placement, although a trend can be detected in the decrease of total N, nitrates, reducing sugars (glucose and fructose), phosphates and oxalates. Sulphates, on the contrary, underwent a small increase.

Nitrogen fertilization modestly affected nitrogen utilization efficiency, in terms of total dry weight and of sugar yield (Table 5). Although significant differences were not found, supplied $\mathrm{N}$ seems to have somewhat improved both indexes, so that fertilizing a crop did not prove a way of increasing yield at the expenses of nutrient efficiency, as it may happen when progressive rates are applied to test crops (LópezBellido and López-Bellido, 2001; López-Bellido et al., 2003). No effect of the application method seems to be detectable. Conversely, a year effect is clearly noticeable: the poor performance observed in 1994, less than half of 1996's NU E for raw sugar, is consistent with the constraint in yield potential of the former year, as previously discussed.

\subsection{Nitrogen in the crop biomass}

During growth cycle, plant uptake in terms of organic and of nitrate nitrogen was affected by $\mathrm{N}$-rate and application way to a different extent. Average amounts of the five samplings performed each year varied remarkably: 285, 146, $90 \mathrm{~kg} \mathrm{ha}^{-1}$ of organic $\mathrm{N}$ and 40,15, 13 of $\mathrm{NO}_{3}^{-}$ $\mathrm{N}$, respectively in 1994, 1995 and 1996. The same considerations may be made at final harvest.

In this case, the average data for the three years were: $476,328,169 \mathrm{~kg} \mathrm{ha}^{-1}$ of organic $\mathrm{N}$ and $62,47,40$ of $\mathrm{NO}_{3}-\mathrm{N}$. The three years, which were submitted to separate ANOVAs because of non-homogeneous variances, showed similar trends for the uptake of organic nitrogen along the season, whereas in the case of nitrate $\mathrm{N}$ the first year appears to have started an earlier accumulation than the following two (Table 6). In the average of the five sampling times, negligible differences in organic $\mathrm{N}$ were observed for fertilizer rates and application methods, apart from the unfertilized check, which often fell beyond the threshold of statistical difference.

Conversely, no significant difference attributable to nitrogen fertilization was found for ni-

Table 6. Organic and nitrate nitrogen uptake as related to sampling time and $\mathrm{N}$ fertilization.

\begin{tabular}{|c|c|c|c|c|c|c|}
\hline \multirow[t]{2}{*}{ Factor } & \multicolumn{3}{|c|}{ Organic $\mathrm{N}$ uptake $\left(\mathrm{kg} \mathrm{ha}^{-1}\right)$} & \multicolumn{3}{|c|}{$\mathrm{NO}_{3}-\mathrm{N}$ uptake $\left(\mathrm{kg} \mathrm{ha}^{-1}\right)$} \\
\hline & 1994 & 1995 & 1996 & 1994 & 1995 & 1996 \\
\hline \multicolumn{7}{|l|}{ Time } \\
\hline 1 & $67 \mathrm{~d}$ & $37 \mathrm{~d}$ & $17 \mathrm{e}$ & $4.8 \mathrm{~b}$ & $0.7 \mathrm{c}$ & $0.4 \mathrm{c}$ \\
\hline 2 & $150 \mathrm{c}$ & $81 \mathrm{c}$ & $51 \mathrm{~d}$ & $10.5 \mathrm{~b}$ & $1.5 \mathrm{c}$ & $0.9 \mathrm{c}$ \\
\hline 3 & $280 \mathrm{~b}$ & $87 \mathrm{c}$ & $86 \mathrm{c}$ & $67.0 \mathrm{a}$ & $1.7 \mathrm{c}$ & $1.4 \mathrm{c}$ \\
\hline 4 & 452 a & $199 \mathrm{~b}$ & $127 \mathrm{~b}$ & $55.8 \mathrm{a}$ & $21.6 \mathrm{~b}$ & $20.7 \mathrm{~b}$ \\
\hline \multirow[t]{2}{*}{5} & $476 \mathrm{a}$ & 328 a & 169 a & $62.1 \mathrm{a}$ & $47.2 \mathrm{a}$ & $39.9 \mathrm{a}$ \\
\hline & $* *$ & $* *$ & $* *$ & $* *$ & $* *$ & $* *$ \\
\hline \multicolumn{7}{|c|}{$\mathrm{N}\left(\mathrm{kg} \mathrm{ha}^{-1}\right)$} \\
\hline 0 & $261 \mathrm{~b}$ & $112 \mathrm{~b}$ & $70 \mathrm{c}$ & 34.4 & 11.5 & 13.8 \\
\hline $60 \mathrm{Br}$. & $267 \mathrm{~b}$ & $155 \mathrm{a}$ & $87 \mathrm{~b}$ & 37.6 & 15.3 & 10.4 \\
\hline 60 Pl. 6 & $282 \mathrm{~b}$ & $142 \mathrm{a}$ & $78 \mathrm{bc}$ & 42.9 & 14.9 & 9.9 \\
\hline $120 \mathrm{Br}$. & $324 \mathrm{a}$ & $175 \mathrm{a}$ & $107 \mathrm{a}$ & 42.3 & 16.3 & 15.4 \\
\hline \multirow[t]{2}{*}{120 Pl. 6} & $291 \mathrm{~b}$ & $148 \mathrm{a}$ & $107 \mathrm{a}$ & 43.0 & 14.6 & 13.8 \\
\hline & $* *$ & $* *$ & $* *$ & n. s. & n. s. & n. s. \\
\hline
\end{tabular}

a, b, c, etc., significantly different means $(\mathrm{P}<0.05)$. Br., broadcast; $\mathrm{Pl}$. 6 , placed at $6 \mathrm{~cm}$. 

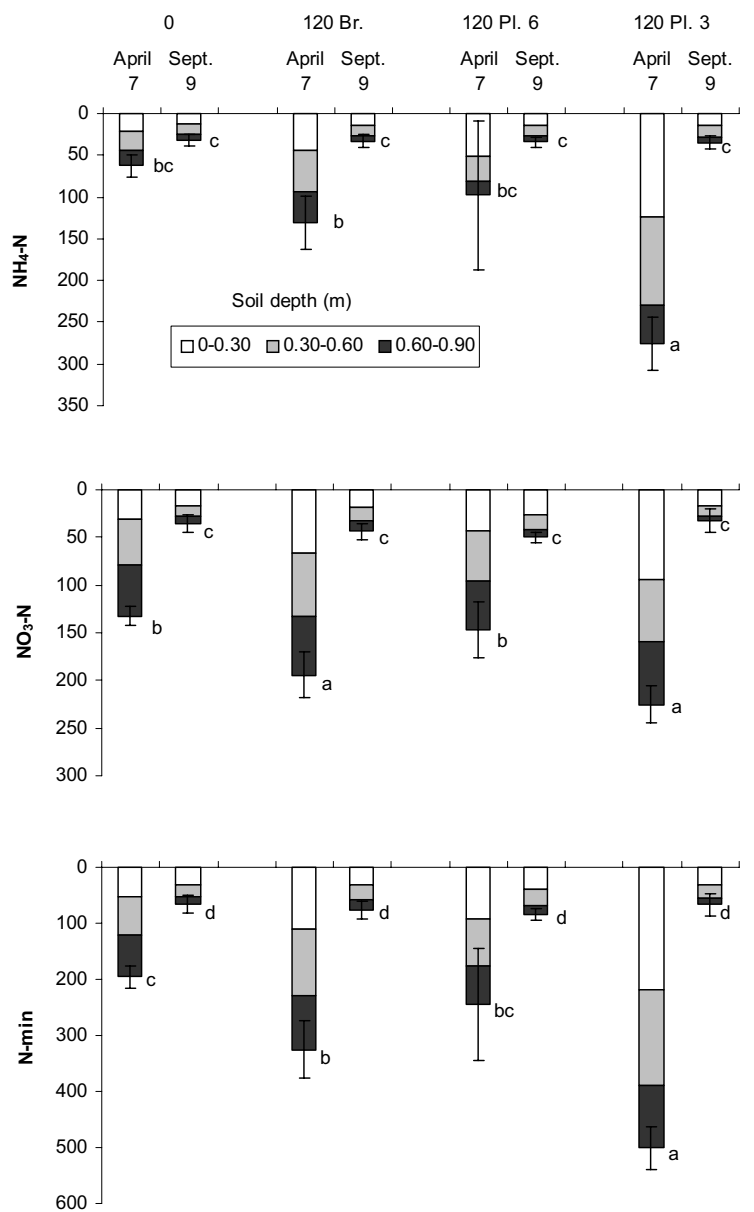

Figure 3. Effects of N-rate and application way ( $0 \mathrm{~kg} \mathrm{ha}^{-1}$; 120 broadcast; 120 placed at $6 \mathrm{~cm} ; 120$ placed at $3 \mathrm{~cm}$ ) on the amount of soil ammonium, nitrate and mineral $\mathrm{N}(\mathrm{kg}$ $\mathrm{ha}^{-1}$ ) on the seed row, at the beginning (April 7; 18 DAS) and at the end (Sept. 9; 174 DAS) of sugar beet cycle (averages 1994-1995).

For all features, significant $(\mathrm{P}<0.01)$ the interaction application way $\mathrm{x}$ sampling time; only for $\mathrm{NO}_{3}-\mathrm{N}$, the interaction application way $\mathrm{x}$ soil depth. Vertical bars, $\pm \mathrm{SE}(\mathrm{n}=8)$; a, $\mathrm{b}$, c, etc., significantly different means $(\mathrm{P}<0.05)$.

trate $\mathrm{N}$, as well as no interaction between sampling time and fertilization for both organic and nitrate N. Nonetheless, when comparing uptake courses during crop growth, broadcasting often prevails over placement in terms of both organic and nitrate nitrogen, especially in the early stages.

At last, partitioning of organic and nitrate $\mathrm{N}$ within the plant organs (roots, crowns, petioles, and leaf blades) was not affected by rates and application ways in any year as well as in any time of the growth cycle.

\subsection{Soil nitrogen}

In 1994-1995, the status of ammonium, nitrate and mineral $\mathrm{N}$ on the seed row at the beginning of growth cycle varied remarkably according to fertilizer application method, while at the end differences levelled substantially off (Figure 3).

This trend did not show significant differences as related to soil layer, and repeated with no between-years interaction, although average levels were much higher in the first year than in the second one: $41 \mathrm{~kg} \mathrm{ha}^{-1}$ versus 17,43 vs. 28 and 84 vs. 45 , respectively for $\mathrm{NH}_{4}-\mathrm{N}, \mathrm{NO}_{3}$ $\mathrm{N}$ and $\mathrm{N}$-min.

In the first sampling, $\mathrm{N}$-availability on seed row rose by an amount roughly corresponding to the applied amount in the case of broadcasting (129 kg ha-1 vs. 120); by only $50 \mathrm{~kg} \mathrm{ha}^{-1}$ with $6 \mathrm{~cm}$-placement, and by $306 \mathrm{~kg} \mathrm{ha}^{-1}$ with 3 $\mathrm{cm}$-placement. The mismatch between applied amounts and soil-nutrient variations may be explained by the short period occurring between application time and soil sampling: nutrient placed at $6 \mathrm{~cm}$ appears not to have fully extended to the row, while at $3 \mathrm{~cm}$ its concentration on the row was so high as to cause seedling phytotoxicity and poor plant stand, as previously discussed.

Applying urea-N seems to have affected the relative share of $\mathrm{NH}_{4}-\mathrm{N}$ and of $\mathrm{NO}_{3}-\mathrm{N}$ in the first phases: the latter represents almost $70 \%$ of the total N-min in the unfertilized check, $60 \%$ in the intermediate situations of broadcasting and $6-\mathrm{cm}$ placement, only $45 \%$ with $3-\mathrm{cm}$ placement. It is perceived that the high fertilizer concentration originated by placement had affected nitrifying bacteria, which could hardly keep the pace of crop needs by transforming a too high amount of ammonia into nitrates, as suggested by other experiences (Guiot et al., 1991).

At the end of the cycle, nutrient availability on the row decreased to only $65-85 \mathrm{~kg} \mathrm{ha}^{-1}$, regardless of the ways and the levels of $\mathrm{N}$-application (Figure 3).

In the average of the two sampling times, placement at $3 \mathrm{~cm}$ showed a higher share of $\mathrm{NO}_{3}-\mathrm{N}$ in the topsoil (43\%), while in the rest of the treatments the nitrate fraction was more evenly present in the three soil layers.

The above-discussed results may explain why the positive results achieved by placing in other experiences were not actually met in the pre- 

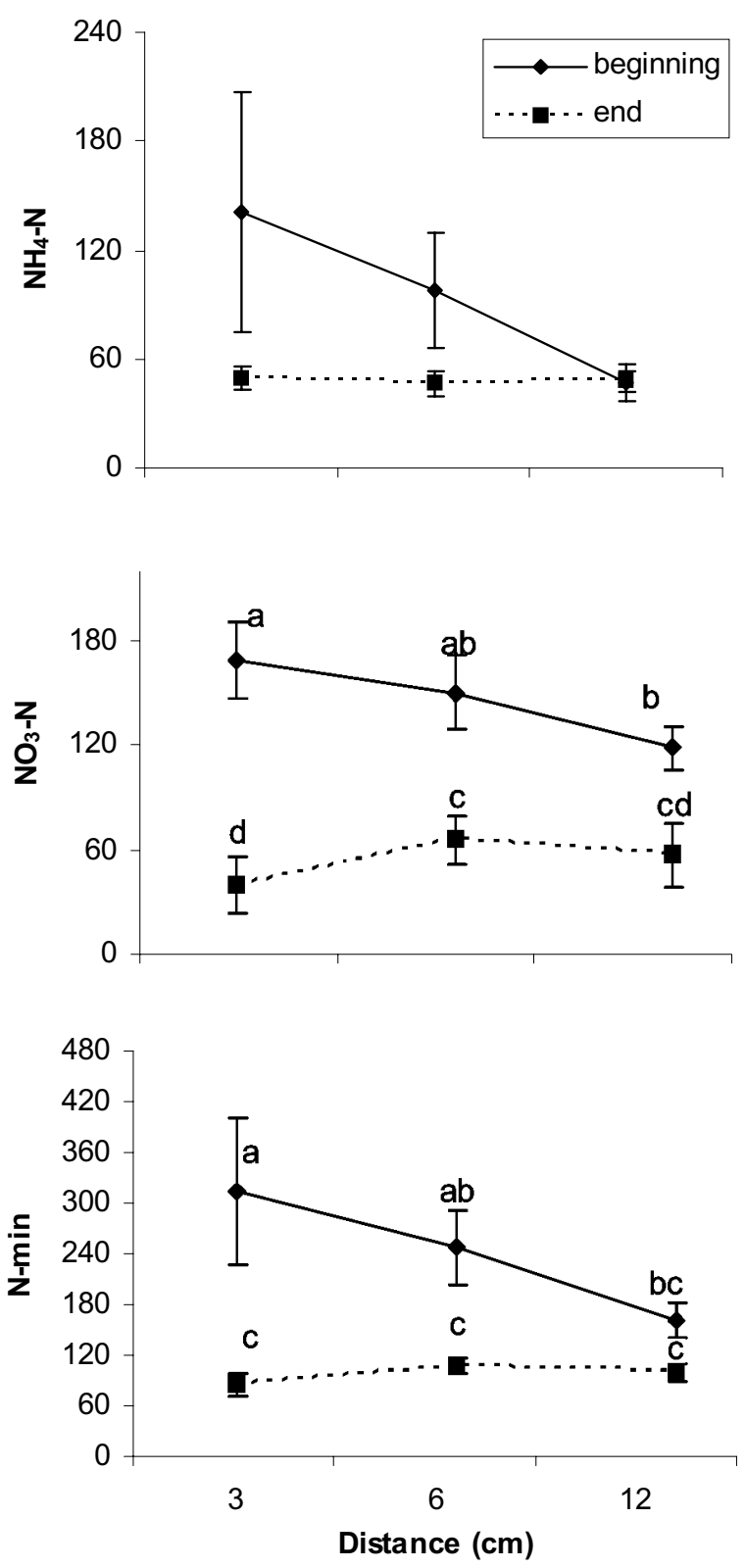

Figure 4. Effects at the beginning (solid line) and at the end of growth cycle (dashed line), of the distance from the point of release in placement, on the amount of ammonium, nitrate and mineral N (kg ha ${ }^{-1}$; soil depth 0-0.90 m). Averages 1994-1995. For nitrate and mineral N, significant $(\mathrm{P}<0.01)$ the interaction distance $\mathrm{x}$ sampling time. Vertical bars, $\pm \mathrm{SE}$ $(\mathrm{n}=8)$; $\mathrm{a}, \mathrm{b}$, c, etc., significantly different means $(\mathrm{P}<0.05)$.

sent research. In fact, while a very close distance from the seed $(3 \mathrm{~cm})$ is not advisable because of negative effects on seedling emergence, a wider spacing $(6 \mathrm{~cm})$ was not able to enhance growth in the first weeks after sowing, at least with urea. This effect is consistent with the ob- served lower nutrient availability on the row, in comparison with the same rate spread over the soil surface.

A further investigation was performed in 1994-1995, in order to assess nutrient distribution in the soil as related to the distance from the point of release in placement. It showed a gradient of time decrease, not associated with soil depth. The interaction between the distance from the point of release $(3-6-12 \mathrm{~cm})$ and the time of sampling (beginning and end of the cycle) was significant for nitrate and mineral $\mathrm{N}$ (Figure 4), while that between the distance form the point of release and soil layers was not. More in detail, at the beginning of the cycle, the amount of $\mathrm{NH}_{4}-\mathrm{N}$ underwent the largest relative decrease when passing from 3 to 6 and to $12 \mathrm{~cm}$ of distance ( 31 and $66 \%$, respectively), but the large data variation prevented these differences from being statistically significant. Conversely, $\mathrm{NO}_{3}-\mathrm{N}$ and $\mathrm{N}$-min lost significant amounts over the same spacings (10 and 28\%; 20 and $46 \%$, respectively). Compared to this pattern, space variation at the end of the growth cycle practically reduced to nil for all the three forms of nitrogen.

Such courses were the same both in 1994 and in 1995, in spite of different rainfalls over the summertime ( 210 vs. $300 \mathrm{~mm}$ ) and over the whole cycle (455 vs. $512 \mathrm{~mm}$ ). In other words, during crop cycle the N-min status of the soil decreased to 32,48 and $67 \%$ of the starting level, respectively at 3,6 and $12 \mathrm{~cm}$ from the row.

At the end of the cycle, nutrient differences in the plant-soil system between broadcasting and placing of $120 \mathrm{~kg} \mathrm{ha}^{-1}$ of $\mathrm{N}$ were always modest, in spite of the large between-years variation (Figure 5): in fact, summing plant organic-N and soil $\mathrm{N}$-min, the differences were about $60 \mathrm{~kg} \mathrm{ha}^{-1}$ in the first two years and only 20 in the third one, always to the advantage of broadcasting. Also moderate were the differences in $\mathrm{N}$-partitioning between plant and soil.

Therefore, it appears that nitrogen in the plant-soil system was much more affected by year than by rate/pattern of application: in 1994, more than $500 \mathrm{~kg} \mathrm{ha}^{-1}$ of $\mathrm{N}$ was present at harvest in the unfertilized crop; in 1996, less than 200.

Differences concerning $\mathrm{NO}_{3}-\mathrm{N}$ were even more limited (Figure 6); in this case, an exception to the above-discussed situation is repre- 

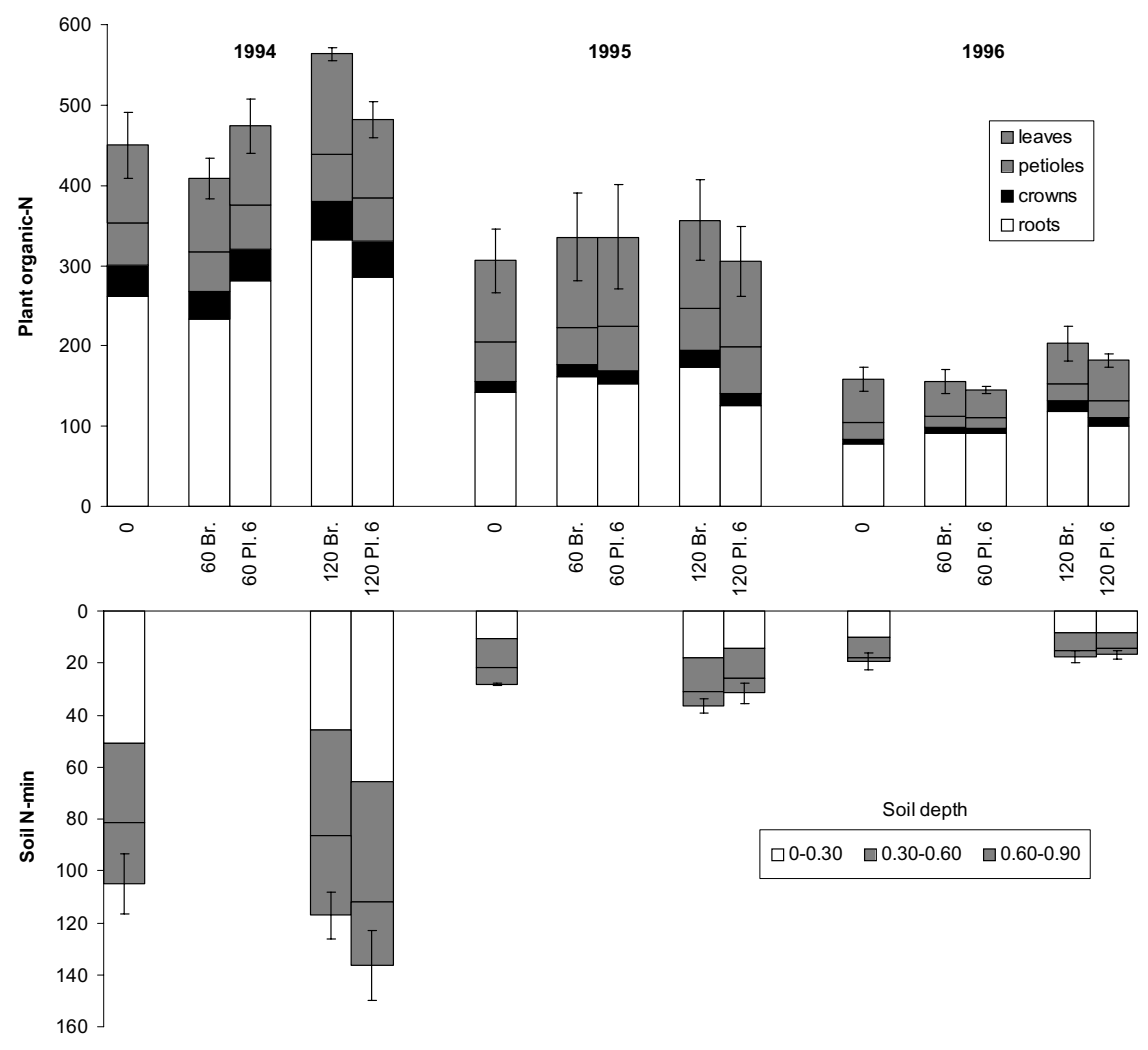

Figure 5. Partitioning of organic $\mathrm{N}$ within the plant and of mineral $\mathrm{N}$ in three soil layers at harvest $(\mathrm{kg}$ ha $^{-1}$ ), as related to $\mathrm{N}$-rate $\left(0,60,120 \mathrm{~kg} \mathrm{ha}^{-1}\right)$ and to application way.

Br., broadcast fertilizer; Pl. 6 , placed at $6 \mathrm{~cm}$. Vertical bars, $\pm \operatorname{SE}(n=4)$.
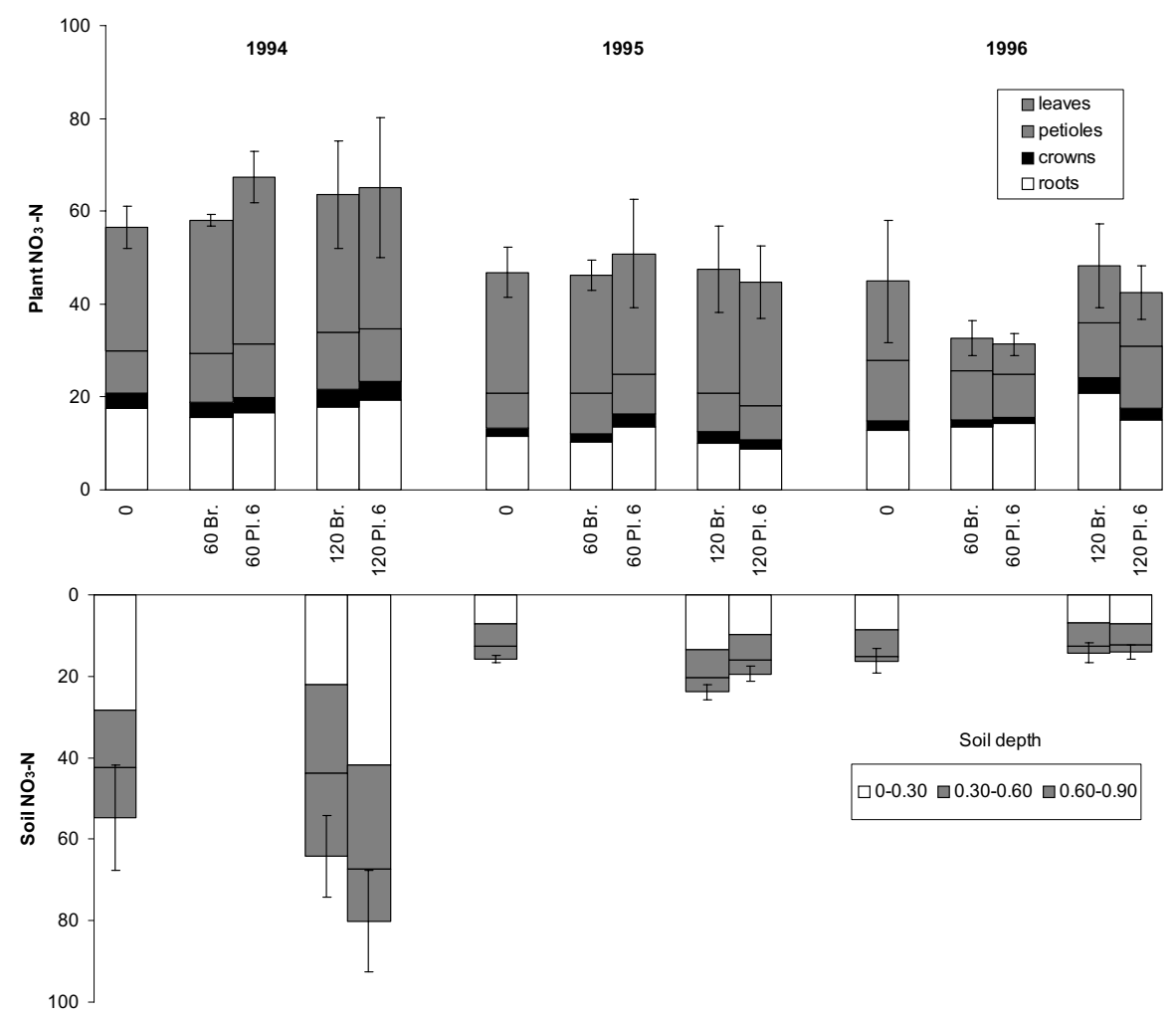

Figure 6. Partitioning of nitrate $\mathrm{N}$ within the plant and in three soil layers at harvest $\left(\mathrm{kg} \mathrm{ha}^{-1}\right)$, as related to N-rate $(0,60,120 \mathrm{~kg}$ $\left.\mathrm{ha}^{-1}\right)$ and to application way.

Br., broadcast fertilizer; Pl. 6, placed at $6 \mathrm{~cm}$. Vertical bars, $\pm \operatorname{SE}(n=4)$. 
sented by a higher concentration for placement in the top soil layer in the first year.

\section{Conclusions}

The comparison between broadcast and placed applications of urea at sowing has confirmed previous experiences carried out in Italy (Barbanti et al., 1992): placing fertilizer has not achieved better results than spreading in terms of yield and quality, as in other European countries.

The residual amount of mineral $\mathrm{N}$ in the soil profile at harvest has showed slight differences in the three years, between the unfertilized check and a rate of $120 \mathrm{~kg} \mathrm{ha}^{-1}$, either placed or broadcast.

In the average of the three years, the differences between the amounts of applied $\mathrm{N}$ and those recovered in the plant-soil system at harvest show that only $43 \%$ of the nutrient supplied was still accountable at the end of the cycle, the rest being lost maybe to leaching, as other experiences in the same area suggest.

Broadcasting showed a higher amount at harvest than placement, so that $63 \%$ of the $\mathrm{N}$ applied with the former technique was still accountable at harvest, only $24 \%$ with the latter. That is to say, apparent losses have been higher in placement than in broadcasting, the opposite of what had been observed in other experiences, in different environmental conditions.

This occurrence seems to explain why this technique, after almost a decade of trials, has not spread in Italy, not only in the case of close distances from the seed $(3-4 \mathrm{~cm})$, but also at wider spacings $(6-8 \mathrm{~cm})$.

Since the present experience has been carried out with a granular fertilizer and a modified machine, it cannot be excluded that different forms of fertilizers and innovative machinery could repropose nitrogen placement as a valid tool to improve N-efficiency and to reduce fertilizer environmental impact.

\section{References}

Amaducci M.T., Mambelli S., Venturi G., Barbanti L., Rosso F. 1992. Localisation de l'azote au semis: premières expériences en Italie. Proceedings of the Mediteranean Committee of the IIRB, Brussels, February 11:1-18.
Barbanti L. 1989. L'azoto, fattore importante nel delicato equilibrio produttivo della bietola. L'Informatore Agrario, 8:43-47.

Barbanti L., Candolo G. 1991. La concimazione fosfatica in localizzazione per la bietola e per la soia. L'Informatore Agrario, 2:67-76.

Barbanti L., Rosso F., Amaducci M. T., Mambelli S., Venturi G. 1992. Localisation de l'azote au semis: deuxième contribution. Proceedings of the Mediteranean Committee of the IIRB, Tunis, October 29:85-96.

Cariolle M. 2000. Fertilizzazione azotata della barbabietola da zucchero in Francia: conoscenze acquisite, tecniche attuali, prospettive. Proceedings of the Symposium "Azoto: una necessità da gestire al meglio". Bardolino (Vr), November 24:13-25.

Cariolle M., Duval R. 1994. Etude de l'enfouissement localisé au semis. Institut Technique de la Betterave, Compte rendu des travaux effectués en 1994:315-327.

Cariolle M., Duval R., Guiraud G. 1991. L'expérience française d'enfouissement localisé de l'azote au semis. Proceedings of the 54th IIRB Winter Congress, Brussels, February 20-21:319-346.

Draycott A.P. 1972. Nitrogen in sugar beet nutrition. App. Science, London, 9-38.

Draycott A.P., Christenson D.R. 2003. Nutrients for sugar beet production. CABI Publishing, 27-29, 153-167.

Draycott A.P., Last P.J., Webb D.J. 1983. Effect of time and method of nitrogen fertiliser applications on soil nitrogen, on seedling establishment and growth, and on yield of sugar beet. Symposium "Nitrogen and sugar-beet", IIRB, Brussels, February 16-17:293-303.

Dunham R.J. 1991a. Fertilizer placement: what can it achieve for sugarbeet. British Sugar Beet Review, 59:2.

Dunham R.J. 1991b. Effects of starter fertilizers close to the seeds. Proceedings of the 54th IIRB Winter Congress, Brussels, February 20-21:369-384.

Dürr C., Fares K., Damay N., Carrera A., Beaudoin N., Machet J.M., Duval R., Maupas F., Postel P. 2003. A description of the development and growth of sugar beet for crop modelling. Advances in Sugar Beet Research, 5:71-85.

Erjala M. 1991. One pass method - the effect on quantity, quality and profitability of sugar beet yield. Proceedings of the 54th IIRB Winter Congress, Brussels, February 20-21:71-83.

Fayolle C. 1991. Localisation de l'azote: vers la reduction des doses. Cultivar, 298-299:34-38.

Giardini L. 1992. Agronomia generale. Patron Editore, Bologna, 462.

Guiot J., Goffart, J.P., Vandergeten J.P., Vanstallen M. 1991. Dynamique de l'azote minéral dans un sol couvert de betteraves sucrières. Influence du mode d'application de la fumure azotée. Proceedings of the 54th IIRB Winter Congress, Brussels, February 20-21:433444. 
Institut Technique de la Betterave 2003. Guide environnement pour la production raisonnée de la betterave sucrière:11-12.

Jensen V., Marcussen C., Smed E. 1983. Nitrogen for sugar beet in Denmark, research and its utilisation. Symposium "Nitrogen and sugar-beet", IIRB, Brussels, February 16-17:305-316.

López-Bellido R.J., López-Bellido L. 2001. Efficiency of nitrogen in wheat under Mediterranean conditions: effects of tillage, crop rotation and $\mathrm{N}$ fertilization. Field Crop Res., 71:31-46.

López-Bellido R.J., López-Bellido L., Castillo, J.E., López-Bellido F.J. 2003. Nitrogen uptake by sunflower as affected by tillage and soil residual nitrogen in a wheat-sunflower rotation under rainfed Mediterranean conditions. Soil and Tillage Research, 72, 1:43-51.

Mambelli S., Grandi S., Barbanti L. 1994. Sugar beet nitrogen uptake in relation to fertilizer $\mathrm{N}$ rate and distribution method. Proceedings 3rd Congress of the European Society of Agronomy (ESA), Abano Terme, 174-175.

Marcussen C. 1991. Placement of N, P, K, to sugar beet. Proceedings of the 54th IIRB Winter Congress, Brussels, February 20-21:401-406.

Oertli J.J. 1980. Controlled-release fertilizers. Fertilizer Research, 1:103-123.

Prummel J. 1957. Fertilizer placement experiments. Plant and Soil, 8, 3:231-253.

Van der Beek M.A., Wilting P. 1991. Comparison of overall and row application of solid nitrogen fertilizer. Proceedings of the 54th IIRB Winter Congress, Brussels, February 20-21:407-432.
Vandergeten J.P., Vanstallen M. 1991a. Influence de l'application localisée de doses raisonnées d'azote sur le rendement et la qualité industrielle de la betterave sucrière. Proceedings of the 54th IIRB Winter Congress, Brussels, February 20-21:297-318.

Vandergeten J.P., Vanstallen M. 1991b. L'azote en betterave sucrières: conception actuelle et recherches nouvelles. IRBAB n. 238.

Vandergeten J.P., Duval R., Vereerstraeten R. 1997. Enfouissement localisé de doses réduites d'engrais azoté en culture betteravière : aspects économiques, mécaniques et écologiques. Proceedings of the 60th IIRB Congress, Cambridge (UK), July 1-3:63-90.

Van Meirvenne M., Vanstallen M., Hofman G., Vandergeten J.P., Demyttenaere P. 1991. Influence of row and broadcasted $\mathrm{N}$ application on the evolution of the mineral nitrogen under sugar beet. Proceedings of the 54th I.I.R.B. Winter Congress, Brussels, February 20-21:445-454.

Venturi G. 1994. Bietola e azoto: considerazioni sulla razionalizzazione della concimazione. L'Informatore Agrario, 2:37-43.

Venturi G., Amaducci M.T. 2002. La bieticoltura e l'ambiente: il caso dell'azoto. L'industria saccarifera italiana, 95, 1:3-15.

Vigoureux A. 1991. Réalisations mécaniques recentes dans le domaine de l'application localisée des engrais. Proceedings of the 54th IIRB Winter Congress, Brussels, February 20-21:385-399.

Vlassak K., Vandergeten J.P., Vanstallen M. 1991. Effect of nitrogen fertilizer placement on yield and quality of sugar beet. Proceedings of the 54th IIRB Winter Congress, Brussels, February 20-21:455-464 